\title{
THE FEDERAL COMMON LAW OF BAIL IN INTERNATIONAL EXTRADITION PROCEEDINGS
}

\author{
Roberto Iraola*
}

\section{INTRODUCTION}

While there is no statutory right to bail in international extradition proceedings, ${ }^{1}$ in Wright $v$. Henkel, ${ }^{2}$ the Supreme Court recognized that the presence of "special circumstances" may render the grant of bail appropriate to one facing extradition to a foreign country. ${ }^{3}$ This acknowledgment by the Court in Wright over one hundred years ago spawned the development of a federal common law on the question of bail in international extradition proceedings. ${ }^{4}$

This Article, which is divided into three parts, examines the evolution of that law. First, and by way of background, the Article provides an overview of foreign requests for extradition. Next, the Article discusses the mechanics of international extradition hearings. Lastly, the Article analyzes the Supreme Court's ruling in Wright and examines the development of the federal case law regarding admission to bail in international extradition proceedings.

\section{OVERVIEW OF EXTRADITION}

Foreign requests for extradition, ${ }^{5}$ one mode of acquiring jurisdiction over

\footnotetext{
* Roberto Iraola, J.D. 1983, Catholic University Law School, Trial Attorney, U.S. Department of Justice, Office of International Affairs. The views expressed herein are those of the author and do not necessarily represent the views of the U.S. Department of Justice or the United States.

1. See In re Extradition of Rouvier, 839 F. Supp. 537, 539 (N.D. Ill. 1993) ('The federal statute implementing United States extradition treaties with other nations ... does not provide for bail."); In re Extradition of Heilbronn, 773 F. Supp. 1576, 1578 (W.D. Mich. 1991) ("There is no statutory right to bail in extradition cases."). See Jeffrey A. Hall, Note, A Recommended Approach to Bail in International Extradition Cases, 86 MICH. L. REv. 599, 599 (1987) ("[I]n international extradition cases ... arrestees have no statutory right to bail largely because of the competing national interest in complying with extradition treaties.") (footnote omitted).
}

2. 190 U.S. 40 (1903).

3. Id. at 63 ("We are unwilling to hold that ... while bail should not ordinarily be granted in cases of foreign extradition ... courts may not in any case, and whatever the special circumstances, extend that relief.").

4. See Rouvier, 839 F. Supp. at 539 ("Given the absence of statutory law governing bail in international extradition proceedings, the question is determined based on federal common law.”); U.S. Dept. of Justice, Criminal Resources Manual, Bail. Hearing § 618 (1997) ("The standards for the release of fugitives in extradition matters are . . . found in case law from the Supreme Court and the lower courts.").

5. Extradition involves "the surrender by one nation to another nation of an individual accused or convicted of an offen[s]e outside of its own territory, and within the territorial jurisdiction of the other, which, being competent to try and punish him, demands the surrender." 
international fugitives, ${ }^{6}$ are governed by 18 U.S.C. $\$ 3184^{7}$ and, with limited exception, by treaty. ${ }^{8}$ Typically, the process is triggered when the Department of State receives a request from a foreign country. 9 . Because the preparation of a formal request for extradition is time-consuming and a fugitive is likely to flee if he learns of it, most treaties provide for the provisional arrest of fugitives while the request is being perfected. ${ }^{10}$ The Department of Justice's Office of International Affairs reviews the request for a provisional arrest warrant and, if sufficient, sends it to the U.S. Attorney for the district where the person sought

Terlinden v. Ames, 184 U.S. 270, 289 (1902). See RESTATEMENT (THIRD) OF THE ForeigN RELATIONS LAW OFTHE UNITED STATES $\$ \$ 474-75$ (1987) ("Extradition is the process by which a person charged with or convicted of a crime under the law of one state is arrested in another state and returned for trial or punishment.").

6. See Valerie Epps, The Development of the Conceptual Framework Supporting International Extradition, 25 LOY. L.A. INT'L \& COMP. L. REV. 369, 371 n.12 (2003) ("The processes of exclusion, deportation, abduction, and rendition or surrender all play a role, together with the historic practice of informal modes of delivery of fugitives by one state to another."). See also Ethan A. Nadelmann, The Evolution of United States Involvement in the International Rendition of Fugitive Criminals, 25 N.Y.U. J. INT'LL. \& POL. 813, $857-81$ (1993) (discussing alternatives to extradition).

7. $\$ 3184$ provides, in relevant part:

Whenever there is a treaty or convention for extradition between the United States and any foreign government ... any justice or judge of the United States, or any magistrate [judge] authorized so to do by a court of the United States, or any judge of a court of record of general jurisdiction of any State, may ... issue [a] warrant for the apprehension of [a] person . . . charged [with having committed within the jurisdiction of any such foreign government any of the crimes provided for by treaty or convention], that he may be brought before such justice, judge, or magistrate [judge], to the end that the evidence of criminality may be heard and considered.

18 U.S.C. $\$ 3184$ (2006). See United States v. Liu Kin-Hong, 110 F.3d 103, 109 (1st Cir. 1997) ("In the United States, the procedures for extradition are governed by statute.").

8. See In re Extradition of Lahoria, 932 F. Supp. 802, 805 (N.D. Tex. 1996) ("International extradition proceedings are governed both by statute . . . and by treaty."). Comity allows for the return of third country nationals (persons who are not citizens, nationals, or residents of the United States), absent a treaty, provided certain conditions are satisfied. 18 U.S.C. § 3181(b) (2006). See Waits v. McGowan, 516 F.2d 203, 208 (3d Cir. 1975) ("International extradition is govemed only by considerations of comity and treaty provisions."). See generally Hall, supra note 1, at 601 ("Treaties and federal statutes govern the extradition process.") (footnotes omitted).

9. See Cornejo-Barreto v. Seifert, 218 F.3d 1004, 1009 (9th Cir. 2000) ("Extradition is ordinarily initiated by a request from the foreign state to the Department of State.").

10. See Duran v. United States, 36 F. Supp. 2d 622, 624 (S.D.N.Y. 1999) ("In order to avoid the flight of a defendant during preparation of a full formal request, many extradition treaties permit a provisional arrest to be made upon receipt of an informal request."). See also U.S. DEP'T OF JUSTICE, U.S. ATTORNEY'S MANUAL, INTERNATIONAL EXTRADITION AND REL ATED $\begin{array}{lllll}\text { MATTERS } & \S & 9-15.230 & \text { (1997), available }\end{array}$ http://www.usdoj.gov/usao/eousa/foia_reading_room/usam/title9/15 mcrm.htm ("Because the time involved in preparing a formal request can be lengthy, most treaties allow for the provisional arrest of fugitives in urgent cases." ); Nathaniel A. Persily, Note, International Extradition and the Right to Bail, 34 STAN. J. INT'L L. 407, 415 (1988) ("Provisional arrest is usually justified as necessary to capture a fugitive who presents a high risk of flight, until such time as the country formally requests extradition."). 
to be extradited is located. ${ }^{11}$ The U.S. Attorney then files a complaint in support of an arrest warrant before a federal judge or magistrate. ${ }^{12}$

After apprehension of the fugitive, the requesting state, through a formal request, provides the U.S. government with the additional information required to carry out the extradition under the treaty. ${ }^{13}$ This ultimately leads to the extradition hearing. ${ }^{14}$ If, at the conclusion of that hearing, the judicial officer "deems the evidence sufficient to sustain the charge"15 - which in international extradition hearings means probable cause ${ }^{16}$ - then he must certify the same to the Secretary of State, who will review the case and determine whether to issue a warrant for the surrender of the person sought to be extradited. ${ }^{17}$ If the

11. See U.S. ATTORNEY's MANUAL, supra note 10, § 9-15.700 (explaining how OIA will review request for sufficiency and then forward it to appropriate district).

12. See 18 U.S.C. \& 3184; Barapind v. Reno, 225 F.3d 1100, 1105 (9th Cir. 2000) ("Once approved, the United States Attorney for the judicial district where the person sought is located files a complaint in federal district court seeking an arrest warrant for the person sought."). See also U.S. DeP'T Of Justice, Criminal ResourCes MANUAL, ROLE Of THE DEPARTMENT OF STATE IN FOREIGN EXTRADITION REQUESTS § 615 (1997) ( "[I]n urgent cases, the prosecutor immediately drafts a complaint for provisional arrest and executes it before a magistrate judge or district judge in the district where the fugitive is located. The judicial officer issues a warrant under the authority of the treaty and 18 U.S.C. $\& 3184 . ")$.

13. See Jeffrey M. Olson, Note, Gauging an Adequate Probable Cause Standard for Provisional Arrest in Light of Parretti v. United States, 48 CATH. U. L. REV. 161, 172 (1998) ("After executing the provisional arrest request, the requesting state furnishes the United States with any additional information that is required for extradition under the governing statute or treaty.") (footnote omitted). See also Lis Wiehl, Extradition Law at the Crossroads: The Trend Towards Extending Greater Constitutional Procedural Protections to Fugitives Fighting Extradition from the United States, 19 MICH. J. INT'L L. 729, 752 (1998) (“[M]ost extradition laws and treaties provide that the alleged fugitive may be arrested and temporarily detained for a period of time to enable the requesting State to furnish the necessary documentation in support of its request for his extradition.").

14. See 18 U.S.C. $\$ 3184$ (noting that the purpose of apprehension after issuance of a warrant is so that person "may be brought before such justice, judge, or magistrate [judge], to the end that the evidence of criminality may be heard and considered.").

15. Id.

16. See In re Extradition of Drayer, 1999 FED App. 0313P (6th Cir.) (“An extradition proceeding is not a forum in which to establish[] the guilt or innocence of the accused; rather, the sole inquiry is into probable cause."). See also In re Extradition of Artt, 158 F.3d 462, 467 (9th Cir. 1998) ("[S]ection 3184 authorizes federal district judges to decide whether there is probable cause to believe that the potential extraditee committed an offense covered by a given extradition treaty."). See generally Steven Lubet \& Morris Czackes, The Role of the American Judiciary in the Extradition of Political Terrorists, 71 J. CRIM. L. \& CRIMINOLOGY 193, 198 (1980) ("The requesting country bears the burden of establishing probable cause to believe that the accused committed the charged offense.") (footnote omitted).

17. See 18 U.S.C. $\$ 3184$ ("[judicial officer] shall certify the same ... to the Secretary of State, that a warrant may issue ... for the surrender of such person"); 18 U.S.C. § 3186 (2006) ("The Secretary of State may order the person committed under section[] $3184 \ldots$. . to be delivered to any authorized agent of such foreign government."). See also Lo Duca v. United States, 93 F.3d 1100, 1103 (2d Cir. 1996) ("[T] he Secretary of State has final authority to extradite the fugitive, but is not required to do so. Pursuant to its authority to conduct foreign affairs, the Executive Branch retains plenary discretion to refuse extradition.").

The prevailing view is that the Secretary of State will seldom reject an extradition request 
extraditee is not surrendered to the requesting country within two months of the commitment order, he may, absent "sufficient cause," be released. ${ }^{18}$ While there is no direct appeal from the magistrate or judge's extradition ruling, ${ }^{19}$ review of the ruling is available through a petition for a writ of habeas corpus under 28 U.S.C. $§ 2241 .^{20}$

\section{THE EXTRADITION HEARING}

Although extradition proceedings are not considered criminal prosecutions, ${ }^{21}$ they are analogous to preliminary hearings. ${ }^{22}$ The governing

after a judicial finding of extraditability. See John G. Kester, Some Myths of United States Extradition Law, 76 GEO. L.J. 1441, 1486 (1988) ("There is little incentive for anyone in the State Department to refuse an extradition request after a court has allowed it. If extradition is then refused by the State Department, it is likely to be for reasons of policy and expediency rather than considerations of fairness or extradition doctrine.") (footnote omitted); John T. Parry, The Lost History of International Extradition Litigation, 43 VA. J. INT'L L. 93, 96 (2002) ("In practice . . . the Secretary rarely exercises discretion, perhaps because the needs of diplomacy outweigh the concerns of individuals who may have committed crimes.") (footnote omitted); Ann Powers, Justice Denied? The Adjudication of Extradition Applications, 37 TEX. INT'L L.J. 277, 288 (2002) ("Although the State Department has the choice to refuse to extradite, even after a court has issued a certificate of extraditability, refusal is an exceedingly rare occurrence.") (footnotes omitted); Elzbieta Klimowicz, Note, Article 15 of the Torture Convention: Enforcement in U.S. Extradition Proceedings, 15 GEo. IMMIGR. L.J. 183, 197 (2000) ("[T] he probability of having the Secretary of State refuse to surrender an extraditable fugitive because of inadmissible evidence is very low. In fact, in the few instances where the Secretary actually refused to surrender such an individual, the evidentiary findings of the magistrate were not questioned, only his treaty construction.") (footnotes omitted).

18. See 18 U.S.C. $\$ 3188$ (2006).

19. See Valenzuela v. United States, 286 F.3d 1223, 1228 n.11 (11 th Cir. 2002) ("There is no direct appeal from extradition decisions."); Bozilov v. Seifert, 983 F.2d 140, 142 (9th Cir. 1993) ("An extradition order cannot be directly appealed.") (footnote omitted); Ahmad v. Wigen, 910 F.2d 1063, 1064-65 (2d Cir. 1990) ("An order granting or denying section 3184 certification is not appealable.").

20. See Barapind v. Enomoto, 400 F.3d 744, 748 n.5 (9th Cir. 2005) ("Decisions of an extradition court are not directly reviewable but may be challenged collaterally by a petition for habeas corpus."). In a habeas proceeding, a petitioner may challenge "whether the magistrate had jurisdiction, whether the offen[s]e charged [wa]s within the treaty and, by a somewhat liberal extension, whether there was any evidence warranting the finding that there was reasonable ground to believe the accused guilty." Fernandez v. Phillips, 268 U.S. 311, 312 (1925). Accord Mainero v. Gregg, 164 F.3d 1199, 1205 (9th Cir. 1999); Sidali v. I.N.S., 107 F.3d 191, 195 (3d Cir. 1997). A final order in a habeas proceeding is subject to review under 28 U.S.C. $\$ 2253$ by the United Sates Court of Appeals for the circuit where the district court is located. See In re Extradition of Artt, 158 F.3d at 468-69.

21. See DeSilva v. DiLeonardi, 181 F.3d 865, 868 (7th Cir. 1999) ("Extradition ... is not a "criminal prosecution."”); Austin v. Healey, 5 F.3d 598, 603 (2d Cir. 1993) (“'A]n extradition hearing is not a criminal prosecution: the order of extraditability expresses no judgment on [petitioner's] guilt or innocence."); In re Extradition of Rovelli, 977 F. Supp. 566, 567 (D. Conn. 1997) ("[E]xtradition proceedings pursuant to treaty are not criminal in nature.").

22. See Benson v. McMahon, 127 U.S. 457, 463 (1888) (noting that an extradition proceeding is "of the character of those preliminary examinations which take place every day in this country before an examining or committing magistrate for the purpose of determining whether a case is made out which will justify the holding of the accused"); David v. Att'y Gen. 
standard at an extradition hearing is probable cause, ${ }^{23}$ which is defined as "the existence of a reasonable ground to believe the accused guilty" sufficient to cause a person of ordinary prudence and caution to conscientiously entertain a reasonable belief of the accused's guilt." 25 The role of the magistrate or judge at the extradition hearing is "to determine whether there is competent evidence to justify holding the accused to await trial, and not to determine whether the evidence is sufficient to justify a conviction." 26

The "[a]dmission of evidence in an international extradition proceeding is within the magistrate's discretion."27 The Federal Rules of Evidence, the Federal Rules of Criminal Procedure, and the Federal Rules of Civil Procedure do not apply. ${ }^{28}$ There is no obligation on the part of the government to provide discovery or produce exculpatory evidence. ${ }^{29}$ A putative extraditee has no right

of the U.S., 699 F.2d 411, 415 (7th Cir. 1983) ("IA]n extradition hearing is of the character of a preliminary hearing and is not to be converted into a full-dress trial.") (footnote omitted).

23. See Jimenez v. Aristeguieta, 311 F.2d 547, 562 (5th Cir. 1962) ("With respect to the evidence upon which the extradition magistrate acted, it must be remembered that the extradition magistrate merely determines probable cause, making an inquiry like that of a committing magistrate and no more."); Polo v. Horgan, 828 F. Supp. 961, 965 (S.D. Fla. 1993) ("To certify an extradition warrant, a magistrate need only find probable cause that the evidence [is] sufficient to sustain the charge.") (internal quotation marks omitted).

24. Escobedo v. United States, 623 F.2d 1098, 1102 (5th Cir. 1980) (citing GarciaGuillern v. United States, 450 F.2d 1189, 1192 (5th Cir. 1971)). Accord Collier v. Vaccaro, 51 F.2d 17, 20 (4th Cir. 1931) ("[The magistrate must] determine whether upon the evidence adduced before him there is reasonable ground to believe that the crime charged has been committed."); In re Extradition of Valles, 268 F. Supp. 2d 758, 772 (S.D. Tex. 2003) ("Probable cause is the existence of reasonable grounds to believe the accused committed the offense charged.") (citation omitted). at 199.

25. Coleman v. Burnett, 477 F.2d 1187, 1202 (D.C. Cir. 1973). Accord Sidali, 107 F.3d

26. Peters v. Egnor, 888 F.2d 713, 717 (10th Cir. 1989) (quoting Collins v. Loisel, 259 U.S. 309, 316 (1922)); cf. Ward v. Rutherford, 921 F.2d 286, 287 (D.C. Cir. 1990) ( "[The extradition hearing is] essentially a 'preliminary examination to determine whether a case is made out which will justify the holding of the accused and his surrender to the demanding nation."') (citation omitted).

27. In re Extradition of Kraiselburd, 786 F.2d 1395, 1399 (9th Cir. 1986) (citation omitted); In re Extradition of Mainero, 990 F. Supp. 1208, 1219 (S.D. Cal. 1997) (judicial officer presiding over the extradition hearing "has wide latitude in admitting evidence") (citation omitted).

28. See In re Requested Extradition of Smyth, 61 F.3d 711, 720-21 (9th Cir. 1995) ("[T] $T$ he rules of evidence and civil procedure that govern federal court proceedings heard under the authority of Article III of the United States Constitution do not apply in extradition hearings that are conducted under the authority of a treaty enacted pursuant to Article II."); FED. R. CRIM. P. 54(b)(5) ("These rules are not applicable to extradition or rendition ....).

29. See Koskotas v. Roche, 931 F.2d 169, 175 (1st Cir. 1991) ("II]n an extradition proceeding, discovery is not only discretionary with the court, it is narrow in scope."); Montemayor Seguy v. United States, 329 F. Supp. 2d 883, 888 (S.D. Tex. 2004) ("The extradition law, the extradition treaty, and the United States Constitution do not require production of exculpatory evidence at an extradition hearing."). But see Demjanjuk v. Petrovsky, 10 F.3d 338, 353-54 (6th Cir. 1993) (recognizing that government must provide exculpatory evidence where it has conducted its own investigation of the offense underlying the extradition request and uncovered exculpatory information); Quinn v. Robinson, 783 F.2d 776, $817 \mathrm{n} .41$ (9th Cir. 1986) ("Although there is no explicit statutory basis for ordering discovery in 
to cross-examine witnesses at an extradition hearing, ${ }^{30}$ where the evidence may consist of hearsay, ${ }^{31}$ and credibility determinations are the province of the extraditing judicial officer. ${ }^{32}$ Additionally, $\$ 3190$ permits the demanding country to introduce properly authenticated evidence gathered at home. ${ }^{33}$

The defenses available at an extradition hearing are limited; for example, "evidence of alibi or of facts contradicting the demanding country's proof of a defense such as insanity may properly be excluded."34 Certified proof of a foreign conviction upon which the extradition request is based ${ }^{35}$ and

extradition hearings . . . the extradition magistrate has the right, under the court's inherent power, to order such discovery procedures as law and justice require.") (citations and internal quotation marks omitted).

30. See Messina v. United States, 728 F.2d 77, 80 (2d Cir. 1984) (“As in the case of a grand jury proceeding, a defendant has no right to cross-examine witnesses or introduce evidence to rebut that of the prosecutor.").

31. See Collins, 259 U.S. at 317 ("[U]nsworn statements of absent witnesses may be acted upon by the committing magistrate, although they could not have been received by him under the law of the State on a preliminary examination."); United States v. Liu Kin-Hong, 110 F.3d 103, 120 (1st Cir. 1997) ("The evidence may consist . . . entirely of hearsay.") (citation omitted); Then v. Melendez, 92 F.3d 851, 855 (9th Cir. 1996) ("[H]earsay evidence is admissible to support a probable cause determination in an extradition hearing ....") (citation omitted); Simmons v. Braun, 627 F.2d 635, 636 (2d Cir. 1980) ("Hearsay evidence is admissible.").

32. See Quinn, 783 F.2d at 815 ("The credibility of witnesses and the weight to be accorded their testimony is solely within the province of the extraditing magistrate.").

33. \$3190, captioned "Evidence on hearing," states:

Depositions, warrants or other papers or copies thereof offered in evidence upon the hearing of any extradition case shall be received and admitted as evidence on such hearing for all the purposes of such hearing if they shall be properly and legally authenticated so as to entitle them to be received for similar purposes by the tribunals of the foreign country from which the accused party shall have escaped, and the certificate of the principal diplomatic or consular officer of the United States resident in such foreign country shall be proof that the same, so offered, are authenticated in the manner required.

18 U.S.C. $\$ 3190$ (2006).

34. Shapiro v. Ferrandina, 478 F.2d 894, 901 (2d Cir. 1973); see Hooker v. Klein, 573 F.2d 1360, 1368 (9th Cir. 1978) (stating alibi or other evidence contradicting proof of probable cause inadmissible); United States v. Peterka, 307 F. Supp. 2d 1344, 1349 (M.D. Fla. 2003) (" $[E] x$ traditees may only introduce evidence to explain rather than contradict the evidence presented by the Government, and the court shall exclude evidence that is proffered to contradict testimony, challenge the credibility of witnesses, or establish a defense to the crimes alleged.") See generally Jacques Semmelman, The Rule of Non-Contradiction in International Extradition Proceedings: A Proposed Approach to the Admission of Exculpatory Evidence, 23 FORDHAM INT'L L.J. 1295 (2000).

35. See Sidali v. INS, 107 F.3d 191, 196 (3d Cir. 1997) ("[A] foreign conviction obtained after a trial at which the accused is present is sufficient to support a finding of probable cause for the purposes of extradition."); Spatola v. United States, 925 F.2d 615, 618 (2d Cir. 1991) ("[A] certified copy of a foreign conviction, obtained following a trial at which the defendant was present, is sufficient to sustain a judicial officer's determination that probable cause exists to extradite."); United States v. Clark, 470 F. Supp. 976, 978 (D. Vt. 1979) ("[T]he certified copy of respondent's Certificate of Conviction in Canada . . . is sufficient proof that probable cause exists that the respondent has been guilty of an offense involving criminality and we hold that document satisfies the requirement that the court find sufficient 'evidence of criminality."'). 
accomplice testimony ${ }^{36}$ are sufficient to establish probable cause. A certificate of extradition ultimately will issue if the judge or magistrate has jurisdiction over the subject matter and the person sought to be extradited, the offense for which extradition was sought was an extraditable offense under a treaty in effect at the time of the request, and competent evidence is presented sufficient to establish probable cause that the extraditee ${ }^{37}$ committed the alleged offense. $^{38}$

\section{THE EVOlution OF THE SPECIAL CIRCUMSTANCES TEST}

As noted previously, although there is no statutory right to bail in international extradition proceedings, ${ }^{39}$ in Wright $v$. Henkel ${ }^{40}$ the Supreme Court recognized that if "special circumstances" are present, bail is available to those facing extradition to a foreign country. ${ }^{41}$ This acknowledgment spawned the development of a federal common law on the question of bail involving foreign extradition. ${ }^{42}$ We now turn to a discussion of the development of that

36. See Bovio v. United States, 989 F.2d 255, 259 (7th Cir. 1993) ("Accomplice testimony can be used to find probable cause[.]"); In re Extradition of Mainero, 990 F. Supp. 1208,1227 (S.D. Cal. 1997) ("[S]elf incriminating statements of accomplices are sufficient to establish probable cause in an extradition hearing.") (citation omitted); In re Extradition of Atta, 706 F. Supp. 1032, 1051 (E.D.N.Y. 1989), aff'd, 910 F.2d (2d Cir. 1990) ("[T] he accomplice testimony evidence, which is, under the rules governing extradition proceedings, deemed credible even without corroboration, sufficiently demonstrates that probable cause exists to support the certification of [petitioner] for extradition.").

An accomplice's recantation of his or her testimony, however, may affect the probable cause analysis. See Eain v. Wilkes, 641 F.2d 504, 510-12 (7th Cir. 1981); In re Extradition of Atuar, 300 F. Supp. 2d 418, 427-31, 434-35 (S.D. W. Va. 2003); In re Extradition of Strunk, 293 F. Supp. 2d 1117, 1125-26 (E.D. Cal. 2003); United States v. Linson, 88 F. Supp. 2d 1123, 1126 (D. Guam 2000); Mainero, 990 F. Supp. at 1221-26; In re Extradition of Garcia, $890 \mathrm{~F}$. Supp. 914, 923-24 (S.D. Cal. 1994); In re Extradition of Contreras, 800 F. Supp. 1462, 1464-69 (S.D. Tex. 1992); Gill v. Imundi, 747 F. Supp. 1028, 1044-47 (S.D.N.Y. 1990); Republic of France v. Moghadam, 617 F. Supp. 777, 782-84 (N.D. Cal. 1985).

37. See Noel v. United States, 12 F. Supp. 2d 1300, 1304 (M.D. Fla. 1998) (identification based on birthday, nationality and appearance in photograph); $c f$. In re Extradition of De Jesus Alatorre Pliego, 320 F. Supp. 2d 947, 950-51 (D. Ariz. 2004) (" $[T]$ here is no probable cause to believe that the [person] who was arrested and sitting in the courtroom at the extradition hearing is the person that was identified by the witnesses as committing the fraud."); In re Extradition of Valles, 268 F. Supp. 2d 758, 775 (S.D. Tex. 2003) ("This is a textbook case of mistaken identity, and the governments of the U.S. and Mexico, in the interests of justice, ought to have conceded that fact.").

38. See, e.g., Atuar, 300 F. Supp. 2d, at 425 (identifying factors). See generally Powers, supra note 17 , at 290 (same).

39. See In re Extradition of Rouvier, 839 F.Supp. 537, 539 (N.D. Ill. 1993).

40. 190 U.S. 40 (1903).

41. Id. at 63 ("We are unwilling to hold that ... while bail should not ordinarily be granted in cases of foreign extradition ... courts may not in any case, and whatever the special circumstances, extend that relief.").

42. While some courts and at least one commentator have characterized the "special circumstances" test as dictum, it has consistently been applied by judges and magistrates since its formulation over one hundred years ago. See Parretti v. United States, 122 F.3d 758, 778 n.24 (9th Cir. 1997), decision withdrawn and appeal dismissed on other grounds, 143 F.3d 508 
law, starting with an analysis of the Court's decision in Wright.

\section{A. The Seed Is Planted-Wright v. Henkel}

In Wright, petitioner, a U.S. citizen, was arrested for fraud under the extradition treaty with Great Britain. ${ }^{43}$ He requested release on bail pending the hearing on the grounds that he suffered from bronchitis, and that his incarceration would aggravate his condition. ${ }^{44}$ The commissioner denied the request because the statute did not allow for bail, and petitioner appealed to the circuit court, which affirmed the commissioner's ruling. ${ }^{45}$

In rejecting petitioner's contention on appeal, the Supreme Court observed that no statute authorizing bail in cases involving foreign extradition existed and that $\S 5270$ of the Revised Statutes, the predecessor to $\S 3184,{ }^{46}$

(9th Cir. 1998) (en banc) ("Cases applying the 'special circumstances' doctrine rely on the dictum in Wright ...."); U.S. ex rel. Carapa v. Curran, 297 F. 946, 953 (2d Cir. 1924) ("[W] hat was said was at best a dictum not being necessary for the decision of the case."); Persily, supra note 10, at 408 ("This dictum planted the seeds of the current federal common law of bail in international extradition proceedings.").

43. Wright, 190 U.S. at $40-41$. Wright was alleged to have published and circulated false corporate reports with the intent to defraud shareholders. Id. at 41 .

44. Id. at 43 (allegation that "petitioner was suffering from bronchitis and a severe chill, which might develop into pneumonia, and that the confinement tended greatly to injure his health and to result in serious impairment").

45. $I d$.

46. The original law was passed in 1848 and has changed little. See An Act for Giving Effect to Certain Treaty Stipulations Between This and Foreign Governments, for the Apprehension and Delivering up of Certain Offenders, ch. 167,9 Stat. 302 (1848) (giving effect to treaty provisions regarding extradition); Persily, supra note 10, at 407 ("The section of the U.S. Code dealing with extradition of international fugitives has remained largely unchanged since its codification over a century and a half ago.") In 1876, section 1 of this act became section 5270 of the Revised Statutes. See Wiehl, supra note 13, at 730-31 n.2. Section 5270 provided:

Whenever there is a treaty or convention for extradition between the government of the United States and any foreign government, any justice of the Supreme Court, circuit judge, district judge, commissioner, authorized so to do by any of the courts of the United States, or judge of a court of record of general jurisdiction of any State, may, upon complaint made under oath, charging any person found within the limits of any State, District or Territory, with having committed with the jurisdiction of any such foreign government any of the crimes provided for by such treaty or convention, issue his warrant for the apprehension of the person so charged, that he may be brought before such justice, judge, or commissioner, to the end that evidence of criminality may be heard and considered. If, on such hearing, he deems the evidence sufficient to sustain the charge under the provisions of the proper treaty or convention, he shall certify the same, together with a copy of all the testimony taken before him, to the Secretary of State, that a warrant may issue upon the requisition of the proper authorities of such foreign government, for the surrender of such person, according to the stipulations of the treaty or convention; and he shall issue his warrant for the commitment of the person so charged to the proper jail, there to remain until such surrender shall be made.

Id. In 1940, section 5270 became codified in 18 U.S.C. $\$ 651$ and, in 1948, it became 18 U.S.C. \& 3184. See Wiehl, supra note 13, at 729 n.2. In 1968, the Federal Magistrate Act 
was inconsistent with admission to bail after a finding of extraditability; at that point, the statute only called for the commissioner or judge to "issue his warrant for the commitment of the person so charged to the proper jail, there to remain until such surrender shall be made." point at which the country demanding extradition performed its obligations under the treaty and the law, it was "entitled to the delivery of the accused on the issue of the proper warrant, and the other government [wa]s under obligation to make the surrender; an obligation which it might be impossible to fulfill if release on bail were permitted." 48 The Court found that this rationale also appeared "generally applicable to release pending examination." 49

Below, the Second Circuit had ruled that, in the absence of a statute, circuit courts lacked the power to grant bail in foreign extradition proceedings. $^{50}$ While affirming the ruling denying Wright's request for bail, the Supreme Court declined to hold that federal courts had "no power in respect of admitting to bail other than as specifically vested by statute, or that, while bail should not ordinarily be granted in cases of foreign extradition, those courts may not in any case, and whatever the special circumstances, extend that relief."

\section{B. Early Cases}

The first reported opinion applying Wright was In re Mitchell. ${ }^{52}$ That case involved a petitioner arrested for fraud under the extradition treaty with Canada. ${ }^{53}$ The arrest warrant was issued on the eve of a civil trial involving petitioner's fortune. $^{54}$ Judge Learned Hand determined that while courts had the power under Wright to grant bail in cases involving foreign extradition, that power "should be exercised only in the most pressing circumstances, and when the requirements of justice [we]re absolutely peremptory." Mitchell, Judge Hand found special circumstances warranted release on bail because of Mitchell's need to engage in "free consultation in the conduct of the civil suit upon which his whole fortune depend[ed]," and the fact that he knew

changed the term "commissioner" to "magistrate" in section 3184. See Federal Magistrates Act, Pub. L. No. 90-578, § 301(a)(3), 82 Stat. 1107, 1115 (1968).

47. Wright, 190 U.S. at 62 (quotation omitted).

48. Id. The Court explained that "[t]he enforcement of the bond, if forfeited, would hardly meet the international demand; and the regaining of the custody of the accused obviously would be surrounded with serious embarrassment." Id.

49. Id.

50. In re Wright, 123 F. 463,464 (C.C.S.D.N.Y. 1903).

51. Wright, 190 U.S. at 63. See generally Carl A. Valenstein, The Right to Bail in United States Extradition Proceedings, 4 MrCH. J. INT'L L. 107,109 (1983) ("The Court did not hint at what might constitute special circumstances but it apparently thought that the potential injury to the accused's health did not qualify.").

52. 171 F. 289 (S.D.N.Y. 1909).

53. Id.

54. Id.

55. Id. 
about the extradition request for some time but had not fled. ${ }^{56}$

Twenty-five years following In re Mitchell, there appear to be only three reported cases addressing the question of bail in foreign extradition proceedings, in more than a passing manner. ${ }^{57}$ In two of these cases, the courts denied bail. ${ }^{58}$ One held the lapse of "several weeks" between the time of arrest and the hearing, and the "discomfort" associated with jail during that period did not present "unusual circumstances" so as to warrant the grant of bail. ${ }^{59}$ In the remaining case, which involved a petitioner arrested in Pennsylvania and charged with obtaining money under false pretenses in Canada, the court initially noted that bail for the offense was available under both Canadian and Pennsylvania law. ${ }^{60}$ Balancing "the small risk of default" against "the injustice of imposing imprisonment in advance of a hearing," which was scheduled no earlier than two months later, the court granted petitioner bail. ${ }^{61}$

\section{Development of the Special Circumstances Test in Federal Common Law}

As foreign extradition requests increased through the years, so did the number of reported district court opinions from magistrates and judges, as well as circuit court decisions, regarding the issue of bail in international extradition matters. In most cases, the requests arose prior to the extradition hearing, either after arrest following the filing of the formal extradition request, ${ }^{62}$ or pursuant to a provisional arrest warrant. ${ }^{63}$ In some cases, the request for bail arose after

56. Id. at 290. Judge Hand further held that upon termination of the civil case, petitioner was to be returned to prison to await resolution of the extradition proceeding. Id.

57. See In re Klein, 46 F.2d 85, 85 (S.D.N.Y. 1930); In re Gannon, 27 F.2d 362, 363 (E.D. Pa. 1928); U.S. ex rel. McNamara v. Henkel, 46 F.2d 84, 84 (S.D.N.Y. 1912). See generally Valenstein, supra note 51, at 109-10 (discussing cases).

58. See McNamara, 46 F.2d at 84; Gannon, 27 F.2d at 363.

59. Klein, 46 F.2d at 85 .

60. Gannon, 27 F.2d at 362 .

61. Id. at 364. The court reasoned that petitioner could "jump his bail, but so likewise he [could] escape his jailers." Id. at 363 . As to the consequences befalling petitioner should he jump bail, the court found:

Should the prisoner default, he will not only forfeit the penal sum of his bond, but will inflict upon himself a punishment many times heavier than any which would follow conviction for the offense with which he is charged, for he must thereafter elude the vigilance of the officers of each and both of two governments whose resources are practically unlimited. Id. at 364 .

62. See In re Extradition of Mironescu, 296 F. Supp. 2d 632, 633-34 (M.D. N.C. 2003); In re Extradition of Sacirbegovic, 280 F. Supp. 2d 81, 82-83 (S.D.N.Y. 2003); In re Extradition of Heilbronn, 773 F. Supp. 1576, 1579 (W.D. Mich. 1991); United States v. Taitz, 130 F.R.D. 442, 443 (S.D. Cal. 1990).

63. See In re Extradition of Orozco, 268 F. Supp. 2d 1115, 1115 (D. Ariz. 2003); In re Extradition of Molnar, 182 F. Supp. 2d 684, 685-86 (N.D. Ill. 2002); Borodin v. Ashcroft, 136 F. Supp. 2d 125, 127 (E.D.N.Y. 2001); In re Extradition of Gonzalez, 52 F. Supp. 2d 725, 728 (W.D. La. 1999); Duran v. United States, 36 F. Supp. 2d 622, 623 (S.D.N.Y. 1999); In re 
the extradition hearing. ${ }^{64}$

Before analyzing the special circumstances which courts have found will support a grant of bail, the following preliminary observations are in order. First, Wright teaches that in foreign extradition cases, there is a presumption against bail. ${ }^{65}$ Second, because international extradition proceedings are not considered criminal cases, ${ }^{66}$ the criteria governing bail under the sections 3141 60 of the Bail Reform Act do not apply. ${ }^{67}$ Third, the absence of a risk of flight does not constitute a special circumstance; it is an independent consideration. ${ }^{68}$

Extradition of Mainero, 950 F. Supp. 290, 292 (S.D. Cal. 1996); In re Extradition of Sutton, 898 F. Supp. 691, 692-93 (E.D. Mo. 1995); In re Extradition of Rouvier, 839 F. Supp. 537, 538-39 (N.D. Ill. 1993); In re Extradition of Nacif-Borge, 829 F. Supp. 1210, 1212-13 (D. Nev. 1993); United States v. Hills, 765 F. Supp. 381, 382-83 (E.D. Mich. 1991); United States v. Tang Yee-Chun, 657 F. Supp. 1270, 1271 (S.D.N.Y. 1987); United States v. Messina, 566 F. Supp. 740,741 (E.D.N.Y. 1983).

64. See Salerno v. United States, 878 F.2d 317, 317 (9th Cir. 1989); Beaulieu v. Hartigan, 554 F.2d 1, 1 (1st Cir. 1977); Hababou v. Albright, 82 F. Supp. 2d 347, 348 (D.N.J. 2000); United States v. Bogue, No. 98-572-M, 1998 U.S. Dist. LEXIS 13208, at *1 (E.D. Pa. Aug. 14, 1998); In re Extradition of Lang, 905 F. Supp. 1385, 1388-89 (C.D. Cal. 1995); Spatola v. United States, 741 F. Supp. 362, 368 (E.D.N.Y. 1990). See also Hills, 765 F. Supp. at 385 ('This 'special circumstances' test applies to requests for release on bail both before and after an extradition hearing; it also applies to requests for release on bond, made after only a 'provisional' arrest pending the extraditing country's submission of formal extradition documents."). See Persily, supra note 10, at 414 ("A fugitive facing extradition petitions for bail at every opportunity: from the moment of arrest, to the hearing on extraditability, continuing to the final appeal for habeas relief, and not ceasing until the instant the fugitive is taken to the requesting country to face trial.").

65. As the Court explained in Wright:

The demanding government, when it has done all that the treaty and the law require it to do, is entitled to the delivery of the accused on the issue of the proper warrant, and the other government is under obligation to make the surrender; an obligation which it might be impossible to fulfill if release on bail were permitted. The enforcement of the bond, if forfeited, would hardly meet the international demand; and the regaining of the custody of the accused obviously would be surrounded with serious embarrassment.

Wright v. Henkel, 190 U.S. 40, 62 (1903). Relying on Wright, lower courts uniformly have held that there is a presumption against bail in international extradition proceedings. See United States v. Liu Kin-Hong, 83 F.3d 523, 524 (1st Cir. 1996); Martin v. Warden, 993 F.2d 824, 827 (11 th Cir. 1993); Salerno, 878 F.2d at 317; In re Extradition of Russell, 805 F.2d 1215, 1216 (5th Cir. 1986) (citation omitted); United States v. Leitner, 784 F.2d 159, 160 (2d Cir. 1986); Beaulieu, 554 F.2d 1 at 2 ;Orozco, 268 F. Supp. 2d at 1116; Molnar, 182 F. Supp. 2d at 686; In re Extradition of Bowey, 147 F. Supp. 2d 1365, 1367 (N.D. Ga. 2001); Borodin, 136 F. Supp. 2d at 128; Hababou, 82 F. Supp. 2d at 351; In re Extradition of Rovelli, 977 F. Supp. 566, 567 (D. Conn. 1997); Mainero, 950 F. Supp. at 293-94; In re Extradition of Morales, 906 F. Supp. 1368, 1373 (S.D. Cal. 1995); Sutton, 898 F. Supp. at 694; In re Extradition of Sidali, 868 F. Supp. 656, 657 (D.N.J. 1994); Rouvier, 839 F. Supp. at 539; Nacif-Borge, 829 F. Supp. at 1214; Heilbronn, 773 F. Supp. at 1578; Hills, 765 F. Supp. at 384.

66. See Mainero, 950 F. Supp. at 293.

67. See Mironescu, 296 F. Supp. 2d at 634; Molnar, 182 F. Supp. 2d at 687; Borodin, 136 F. Supp. 2d at 128; Huerta, 52 F. Supp. 2d at 735; Mainero, 950 F. Supp. at 29; Rouvier, 839 F. Supp. at 539; Nacif-Borge, 829 F. Supp. at 1213. See also Bail Reform Act of 1966, 18 U.S.C. $\S \S 3141-60$ (2006).

68. See Russell, 805 F. $2 \mathrm{~d}$ at 1217; Leitner, 784 F.2d at 161; In re Extradition of Sacirbegovic, 280 F. Supp. 2d 81, 88 (S.D.N.Y. 2003); Orozco, 268 F. Supp.2d at 1117; 
Lastly, the petitioner has the burden to establish special circumstances warranting his admission to bail. ${ }^{69}$ With these considerations in place, we now turn to the factors which courts have evaluated in ascertaining whether special circumstances supporting admission to bail in an international extradition proceeding existed.

Courts have recognized that the following factors, either individually or in unison with one or more other factors, ${ }^{70}$ may constitute "special circumstances" so as to support admitting a putative extraditee to bail: (i) a substantial likelihood of success at the hearing; ${ }^{71}$ (ii) availability of bail for the underlying charge in the requesting country; ${ }^{72}$ (iii) the requesting country's allowance of admission to bail for those facing an extradition hearing for the same offense; ${ }^{73}$ (iv) the likelihood of success in defending against the action in the requesting country; ${ }^{74}$ (v) a delayed extradition hearing; ${ }^{75}$ (vi) a severe health

Hababou, 82 F. Supp.2d at 352; Rovelli, 977 F. Supp. at 568; Sutton, 898 F. Supp. at 696; In re Extradition of Siegmund, 887 F. Supp. 1383, 1387 (D. Nev. 1995); Rouvier, 839 F. Supp. at 541; Tang Yee-Chun, 657 F. Supp. at 1272. Cf. Salerno, 878 F.2d at 318 ("[Petitioner] contends that because he is not a flight risk, he is entitled to bail pending the appeal of the denial of his petition for a writ of habeas corpus. That is not the criteria for release in an extradition hearing.") (citation omitted).

Some courts reason that "risk of flight is more in the nature of a condition precedent to going forward with any determination of the existence of 'special circumstances' that could overcome the presumption against bail." Molnar, 182 F. Supp. $2 \mathrm{~d}$ at 687. See In re Extradition of Valles, No. M-02-008, 2002 Dist. LEXIS 26710, at * 3 (S.D. Tex. 2002); United States v. Taitz, 130 F.R.D. 442, 445 (S.D. Cal. 1990). Other courts have found that "the best approach first explores special circumstances, and then, only after a finding of special circumstances examines risk of flight." Nacif-Borge, 829 F. Supp. at 1216. See also Mainero, 950 F. Supp. at 295; Morales, 906 F. Supp. at 1373; Rouvier, 839 F. Supp. at 542.

69. See Molnar, 182 F. Supp. 2d at 686; Morales, 906 F. Supp. at 1373; Taitz, 130 F.R.D. at 444 . Some courts have noted that the putative extraditee must establish special circumstances by clear and convincing evidence. See In re Extradition of Gonzalez, 52 F. Supp. $2 d 735$ (W.D. La. 1999); Mainero, 950 F. Supp. at 294; Nacif-Borge, 829 F. Supp. at 1215. See generally Hall, supra note 1, at 616 ("[B]ecause extradition defendants often have a demonstrated propensity to flee, and because the relevant proof is generally more accessible to defendants, the burden of proof in bail decisions in international extradition cases is properly on the accused.").

70. See Sacirbegovic, 280 F. Supp. 2d at 88; Orozco, 268 F. Supp. 2d at 1117; Molnar, 182 F. Supp. 2d at 689; Nacif-Borge, 829 F. Supp. at 1216; Sidali, 868 F. Supp. at 658.

71. See United States v. Liu Kin-Hong, 83 F.3d 523, 524-25 (1st Cir. 1996); Salemo, 878 F.2d at 317; Mironescu, 296 F. Supp. 2d at 634-35; Sacirbegovic, 280 F. Supp.2d at 88; Gonzalez, j2 F. Supp. 2d at 735; Mainero, 950 F. Supp. at 294; Sidali, 868 F. Supp. at 658; Rouvier, 839 F. Supp. at 542; Nacif-Borge, 829 F. Supp. at 1216.

72. See Gonzalez, 52 F. Supp. 2d at 736; Morales, 906 F. Supp. at 1376-77; Nacif-Borge, $829 \mathrm{~F}$. Supp. at 1221 . Some courts, however, have rejected the argument that the availability of bail for the underlying charge in the requesting country can ever constitute a special circumstance warranting the grant of bail. Sacirbegovic, 280 F. Supp. 2d at 87; Orozco, 268 F. Supp. 2d at 1117; Sutton, 898 F. Supp. at 695; Siegmund, 887 F. Supp. at 1386; Rouvier, 839 F. Supp. at 540-41.

73. See Taitz, 130 F.R.D. at 446-47.

74. See In re Extradition of Bowey, 147 F. Supp. 2d 1365, 1368 (N.D. Ga. 2001).

75. See Liu Kin-Hong, 83 F.3d at 524; United States v. Williams, 611 F.2d 914, 915 (1st Cir. 1979); Morales, 906 F. Supp. at 1375. 
problem; ${ }^{76}$ (vii) probable lengthy delay as a result of the extradition proceeding itself and appeals therefrom; ${ }^{77}$ and (viii) the age of the extraditee and availability of a suitable detention facility. ${ }^{78}$ Conversely, courts have ruled that the following factors or conditions do not constitute special circumstances in support of admission to bail: (i) American citizenship; ${ }^{79}$ (ii) the pendency of naturalization proceedings; ${ }^{80}$ (iii) the desire to take the dental board examination; ${ }^{81}$ (iv) providing service as a medical doctor; ${ }^{82}(\mathrm{v}$ ) the discomfort of jail; ${ }^{83}$ (vi) political status; ${ }^{84}$ (vii) the need for a special diet on account of having only one kidney and associated health concerns; ${ }^{85}$ (viii) an offer to compromise the underlying charge in the requesting country; ${ }^{86}$ (ix) the need to consult with counsel about the extradition proceeding; ${ }^{87}(\mathrm{x})$ pending civil or criminal litigation (whether or not related to the extradition proceeding); ${ }^{88}$ (xi) availability of electronic monitoring; ${ }^{89}$ and (xii) the failure of the requesting

76. See Salemo, 878 F.2d at 317; Rouvier, 839 F. Supp. at 541-42; In re Extradition of Hamilton-Byrne, 831 F. Supp. 287, 290-91 (S.D.N.Y. 1993); Nacif-Borge, 829 F. Supp. at 1217. The poor health of a member of the putative extraditee's family was held not to be a special circumstance. Lo Duca v. United States, No. CV-95-713, 1995 U.S. Dist. WL 428636, at *16 (E.D.N.Y. July 7, 1995).

77. See In re Extradition of Kirby, 106 F.3d 855, 863 (9th Cir. 1996); Taitz,130 F.R.D. at 445-46; Sutton, 898 F. Supp. at 695.

78. See Hu Yau-Leung v. Soscia, 649 F.2d 914, 920 (2d Cir. 1981); cf. In re Extradition of Sidali, 868 F. Supp. 656, 658 (D.N.J. 1994) ("Here, we are not dealing with a juvenile ... and, unfortunately or not, the United States contains a proliferation of suitable federal prison facilities for adult detainees.").

79. See Martin v. Warden, 993 F.2d 824, 827-28 (11th Cir. 1993); In re Extradition of Sacirbegovic, 280 F. Supp. 2d 81, 84 (S.D.N.Y. 2003).

80. See In re Extradition of Orozco, 268 F. Supp. 2d 1115, 1117 (D. Ariz. 2003).

81. See id.

82. See In re Extradition of Heilbronn, 773 F. Supp. 1576, 1581-82 (W.D. Mich. 1991).

83. See Borodin v. Ashcroft, 136 F. Supp. 2d 125, 131 (E.D.N.Y. 2001); In re Klein, 46 F.2d 85 (S.D.N.Y. 1930).

84. See Borodin, 136 F. Supp. $2 d$ at 131.

85. See In re Extradition of Nacif-Borge, 829 F. Supp. 1210, 1216-17 (D. Nev. 1993).

86. See id. at 1218.

87. See In re Extradition of Smyth, 976 F.2d 1535, 1535-36 (9th Cir. 1992); In re Extradition of Russell, 805 F.2d 1215, 1217 (5th Cir. 1986); In re Extradition of Rovelli, 977 F. Supp. 566, 569 (D. Conn. 1997); United States v. Hills, 765 F. Supp. 381, 388 (E.D. Mich. 1991); In re Extradition of Koskotas, 127 F.R.D. 13, 18 (D. Mass. 1989); United States v. Tang Yee-Chun, 657 F. Supp. 1270, 1272 (S.D.N.Y. 1987); United States v. Messina, 566 F. Supp. 740, 743 (E.D.N.Y. 1983).

88. See Russell, 805 F.2d at 1217; Hababou v. Albright, 82 F. Supp. 2d 347, 351-52 (D.N.J. 2000); Rovelli, 977 F. Supp. at 569; Hills, 765 F. Supp. at 387; Koskotas, 127 F.R.D. at 18. But see In re Extradition of Bowey, 147 F. Supp. 2d 1365, 1368 (N.D. Ga. 2001) ("[T] he civil proceedings in Cobb County Superior Court are directly related to the reasons for [petitioner's] extradition and the resolution of the issues in that matter could directly affect the prosecution of the charges he faces in France."); In re Mitchell, 171 F. 289, 289-90 (S.D.N.Y. 1909) (need to engage in "free consultation in the conduct of the civil suit upon which [extraditee's] whole fortune depend[ed]" constituted special circumstances warranting his release on bail).

89. See Rovelli, 977 F. Supp. at 569; Hills, 765 F. Supp. at 389. 
country to provide the putative extraditee with credit on his or her sentence for time served in American custody. ${ }^{90}$

\section{A Bump on the Road}

The federal common law regarding bail in foreign extradition matters evolved within the framework of the special circumstances test discussed above until the Ninth Circuit decided Parretti v. United States. ${ }^{91}$ In Parretti, the court held, in part, that Parretti's detention without bail before his extradition hearing, after the district court had determined that he did not pose a risk of flight, violated his right to due process under the Fifth Amendment. ${ }^{92}$ Although that opinion subsequently was withdrawn by the Ninth Circuit sitting en banc when it applied the fugitive disentitlement doctrine, the panel's treatment and analysis of the bail issue may influence the decisions of judges or magistrates in the future on this question, and thus, merits discussion here. ${ }^{93}$

In Parretti, the circuit court began its discussion by recognizing that the district court had not abused its discretion when it determined that petitioner

90. See In re Extradition of Kirby, 106 F.3d 855, 863 (9th Cir. 1986).

91. 122 F.3d 758 (9th Cir. 1997), appeal dismissed on other grounds, 143 F.3d 508 (9th Cir.) (en banc), cert. denied, 525 U.S. 877 (1998). An earlier version of the Parretti opinion is found at 112 F.3d 1363 (9th Cir. 1997). Given the court's en banc ruling, the panel decision has no precedential value. See In re Extradition of Kyung Joon Kim, No. CV 04-3886, 2004 U.S. Dist. LEXIS 12244, at *3 n.1 (C.D. Cal. July 1, 2004) (recognizing that the earlier Parretti opinion "is not the law in th[e] [Ninth] Circuit.").

92. Parretti, 122 F.3d at 781. In Parretti, petitioner, an Italian citizen, was arrested pursuant to a provisional arrest warrant under the extradition treaty between the United States and France. Id. at 761. The warrant was based on the complaint of an Assistant U.S. Attorney acting on behalf of the French government. Id. The complaint alleged that petitioner had been charged in an arrest warrant issued in France with various business-related crimes, that the crimes were extraditable offenses under the treaty, and that France had requested petitioner's provisional arrest. Id.

Following his arrest, petitioner argued at his bail hearing and his habeas petition that the provisional warrant violated the Fourth Amendment on two grounds. First, it was not based on any evidence that he had committed any of the offenses with which he had been charged in the French warrant. Id. Secondly, petitioner maintained that the magistrate judge had failed to make a probable cause determination. Id. at 762. The district court denied the petition and, on appeal, the United States Court of Appeals for the Ninth Circuit reversed, holding that the government had failed to make the necessary evidentiary showing of probable cause to believe that petitioner had committed an extraditable crime. Id. at 766 . The court also ruled that detention without bail violated petitioner's due process rights under the Fifth Amendment. Id. at 763-81.

93. See Parretti v. United States, 143 F.3d 508 (9th Cir.) (en banc), cert. denied, 525 U.S. 877 (1998). The fugitive disentitlement doctrine establishes that a "fugitive from justice may not seek relief from the judicial system whose authority he or she evades." Martha B. Stolley, Note, Sword or Shield: Due Process and the Fugitive Disentitlement Doctrine, 87 J. CRIM. L. \& CrIMINOLOGY, 751, 752 (1997) (footnote omitted). Equitable in nature, see In re Prevot, 1995 FED App. 0212P (6th Cir.), the doctrine has been applied in criminal and civil cases, at both the trial and appellate levels. See Pesin v. Rodriguez, 244 F.3d 1250, 1252 (1 1 th Cir. 2001). 
had not established special circumstances warranting his admission to bail. ${ }^{94}$ But that was not the end of the inquiry, for Parretti argued that even if special circumstances were not present, denying him admission to bail, absent a finding of risk of flight or danger to the community, violated his right to due process under the Fifth Amendment. ${ }^{95}$

In responding to this argument, the court preliminarily noted that Wright and its progeny had not foreclosed the due process argument that Parretti presented. ${ }^{96}$ It then turned to the heart of the government's contention -- that "its interest in fulfilling [its] obligations under extradition treaties [wa]s sufficiently compelling to justify pre-hearing detention regardless of how slight the risk that the detainee will jump bail and make it impossible to deliver him to the requesting government. ${ }^{97}$ The court found that the interest, while weighty, was not "materially different from and greater than [the government's] interest in the enforcement of our own criminal laws." 98 In that regard, the only governmental interest generally deemed sufficient to justify pre-hearing detention absent risk of flight was protection of community safety. ${ }^{99}$ But the government had not presented a public safety argument, and the court rejected the contention that a comparable interest could be found "in avoiding the risk of being unable to carry out its treaty obligations, however attenuated that risk may be." 100 In its ruling, the court made clear that it was addressing the issue of bail prior to a finding of extraditability. ${ }^{101}$

94. Parretti, 122 F.3d at 777. Parretti had argued that the following four special circumstances warranted his admission to bail: (i) he was likely to succeed at the extradition hearing; (ii) his detention interfered with his ability to participate in civil suits in which he was engaged; (iii) his detention impacted his health; and (iv) France had not sought his extradition while he was in Italy. Id.

95. Id.

96. Id. at 778 ("[T]he government contends that it cannot be presumed that this court's and the Supreme Court's earlier decisions ignored due process concerns in adopting and applying the 'special circumstances' standard .... Not surprisingly, the government cites no authority in support of this startling proposition.") (internal quotation marks omitted).

97. Id.

98. Id. at 779. The court observed:

In the last analysis, the purpose of extradition treaties is to strengthen our hand in enforcing our laws through the cooperation of other countries in apprehending fugitives. Yet the government implicitly argues that the law enforcement interest served by extradition treaties is somehow different from and greater than its interest in enforcing our domestic laws. The government fails to suggest any difference, and we can fathom none.

Id.

99. Id.

100. Id. at 780 (footnote omitted).

101. Id. ("Our holding is a limited one: until such time as an individual is found to be extraditable, his or her Fifth Amendment liberty interest trumps the government's treaty interest unless the government proves to the satisfaction of the district court that he or she is a flight risk.") See In re Extradition of Campillo Valles, 36 F. Supp. 2d 1228, 1229 (S.D. Cal. 1998) (applying Parretti and holding that petitioner was not entitled to bail because he posed a risk of flight and was a danger to the community). 
Since the Ninth Circuit's withdrawal of the panel decision in Parretti, there have been several opinions from magistrates granting bail in international extradition proceedings. ${ }^{102}$ In those cases, special circumstances were found to be present; therefore, there was no need to consider whether, absent the presence of such circumstances and a risk of flight, it would have been a violation of due process not to admit petitioners to bail. ${ }^{103}$

It is reasonable to assume, however, that the due process argument employed by the panel in Parretti has been, and will continue to be, made by putative extraditees in international extradition proceedings. In evaluating a due process challenge, at least two points must be considered. First, in Wright, the petitioner maintained that denial of access to bail "constitute[d] a deprivation of liberty without due process of law." 104 Therefore, an argument can be made that the Court at least implicitly rejected that contention when it upheld the denial of the bail application. ${ }^{105}$ Second, detention in international extradition proceedings is not intended to be punitive; ${ }^{106}$ rather, it is designed to protect the government's weighty interests in fulfilling its treaty obligations. ${ }^{107}$

102. See, e.g., In re Extradition of Bowey, 147 F. Supp. 2d 1365 (N.D. Ga. 2001) (no risk of flight or danger to community; need to participate in divorce proceeding directly related to extradition; likelihood of success in defending against criminal action in requesting country); In $r e$ Extradition of Gonzalez, 52 F. Supp. 725 (W.D. La. 1999) (no risk of flight; substantial likelihood of success at extradition hearing because identification evidence lacked indicia of reliability). See also In re Extradition of Valles, No. M-02-008, 2002 U.S. Dist. LEXIS 26711, at *4-5 (S.D. Tex. Sept. 16, 2002) (alluding to factors identified in a decision by the Board of Immigration Appeals).

103. See Valles, 2002 U.S. Dist. LEXIS 26711, at *4-5.

104. Wright v. Henkel, 190 U.S. 40, 43 (1903).

105. The Parretti panel concluded that while the issue of due process may have "lurk[ed] in the record," it was not ruled upon by the Court. Parretti v. United States, 122 F.3d 758, 778 (9th Cir. 1997) (internal quotation marks omitted).

106. See United States v. Salerno, 481 U.S. 739, 747 (1987) ("Unless Congress expressly intended to impose punitive restrictions, the punitive/regulatory distinction turns on "whether an alternative purpose to which [the restriction] may rationally be connected is assignable for it, and whether it appears excessive in relation to the alternative purpose assigned [to it.]") (quoting Kennedy v. Mendoza-Martinez, 372 U.S. 144, 168-69 (1963)).

107. See In re Extradition of Orozco, 268 F. Supp. 2d 1115, 1116-17 (D. Ariz. 2003); Hababou v. Albright, 82 F. Supp. 2d 347, 352 (D.N.J. 2000); United States v. Hills, 765 F. Supp. 381, 384-85 (E.D. Mich. 1991). As explained by one commentator:

When a requesting nation has followed the procedures prescribed by an extradition treaty and the accused is found to be extraditable, the United States has a substantial interest in surrendering him in compliance with the treaty. First, the United States has a clear interest in ridding itself of foreign criminals, especially since extradition is normally used only for those charged with, or convicted of, serious, often violent, crimes. Without a reliable extradition practice, the United States would risk becoming a haven for such dangerous international fugitives.

Perhaps a more important reason for the United States to extradite in compliance with its extradition treaties is the likely reciprocal consequences of noncompliance. If the United States fails to deliver a bona fide extraditee, it will breach its obligation under international law. In response, the aggrieved nation 


\section{E. Judicial Review of Bail Determinations}

As noted earlier, an extraditee can seek review of a ruling certifying his extraditability through a petition for a writ of habeas corpus. ${ }^{108}$ But what about bail determination? Is the denial of bail appealable? If so, can the government also appeal the grant of bail?

Putative extraditees denied bail by a magistrate have obtained review before a district court judge by way of appeal, ${ }^{109}$ petition for a writ of habeas corpus, ${ }^{110}$ or through a motion seeking reconsideration of the original bail application. ${ }^{111}$ Some courts have held that the standard for review is whether there were reasonable grounds for the magistrate's denial of bail. ${ }^{112}$ Other courts have observed that the magistrate's decision is subject to de novo review. ${ }^{113}$ Extraditees also have appealed a district court's denial of a request for admission to bail to the circuit court. ${ }^{114}$

When the government has appealed a magistrate's grant of bail to a district judge, some courts have held that a district court judge lacks jurisdiction to review that decision. ${ }^{15}$ Other courts have permitted review by way of

may reciprocate by breaching its own obligation to extradite criminals to the United States, possibly debilitating United States law enforcement in future cases. . . Releasing an extraditee on bail, which provides an opportunity to abscond, puts this interest in treaty compliance at risk.

Hall, supra note 1, at 603-04 (footnotes omitted). See Parretti, 122 F.3d 758, 786 (9th Cir.), appeal dismissed on other grounds, $143 \mathrm{~F} .3 \mathrm{~d} 508\left(9^{\text {th }}\right.$ Cir.) (en banc), cert. denied 525 U.S. 877 (1998) ("The failure of a country to deliver on its promises can have many unpredictable consequences quite apart from the effects on its ability to secure the assistance of others when it is the one that desires to obtain or exercise the right to extradite." ) (Reinhardt, J., concurring).

108. See supra note 20.

109. See In re Extradition of Bowey, 147 F. Supp. 1365, 1366 (N.D. Ga. 2001); In re Extradition of Hamilton-Byrne, 831 F. Supp. 287, 288 (S.D.N.Y. 1993); Hills, 765 F. Supp. at 384 n.3; United States v. Tang Yee-Chun, 657 F. Supp. 1270, 1271 (S.D.N.Y. 1987). But see In re Extradition of Siegmund, 887 F. Supp. 1383, 1385 (D. Nev. 1995) ("Though [petitioner] has filed what he terms an 'Appeal of Magistrate's Detention Order (Pursuant to 18 U.S.C. \& $3145(\mathrm{~b}))$, ' . . we can, and do, deem the document a habeas petition and proceed on the merits.").

110. See Borodin v. Ashcroft, 136 F. Supp. 2d 125, 128 (E.D.N.Y. 2001); Hababou, 82 F. Supp. 2d at 348; United States v. Bogue, No. 98-572-M, 1998 U.S. Dist. LEXIS 16784, at *1-2 (E.D. Pa. May 14, 1998); Siegmund, 887 F. Supp. at 1385; In re Extradition of Russell, 647 F. Supp. 1044, 1046-47 (S.D. Tex), aff'd, 805 F.2d 1215, 1216-17 (5th Cir. 1986).

111. See Duran v. United States, 36 F. Supp. 2d 622, 627 (S.D.N.Y. 1999); Lo Duca v. United States, No. CV-95-713 1995, WL 428636, at *15 (E.D.N.Y. July 7, 1995).

112. See Russell, 647 F. Supp. at 1047; Koskotas v. Roche, 740 F. Supp. 904,918 (D. Mass. 1990), aff'd, 931 F.2d 169 (1 st Cir. 1991).

113. See Hills, 765 F. Supp. at 384 n.3.

114. See Martin v. Warden, 993 F.2d 824, 827 (11th Cir. 1993); In re Extradition of Russell, 805 F.2d 1215, 1216 (5th Cir. 1986); United States v. Leitner, 784 F.2d 159, 160 (2d Cir. 1986); Magisano v. Locke, 545 F.2d 1228, 1229 (9th Cir. 1976).

115. See In re Extradition of Ghandtchi, 697 F.2d 1037, 1037-38 (11 th Cir. 1983), vacated as moot, 705 F.2d 1315 (11th Cir. 1983) ("The district court properly concluded that it lacked jurisdiction to review the magistrate's decision."); In re Extradition of Krickemeyer, $518 \mathrm{~F}$. Supp. 388, 389 (S.D. Fla. 1981) ("[S]ince the Magistrate is empowered to make final disposition of the extradition matter, the district court is not vested with the power to review the 
appeal, ${ }^{116}$ or by a motion for reconsideration of the magistrate's order. ${ }^{117}$ At the appellate level, without discussing the source of their jurisdiction, circuit courts consistently have entertained appeals by the government from a district court's order admitting an extraditee to bail. ${ }^{118}$ The Ninth Circuit has ruled that a district court's decision to grant bail to a putative extraditee is a "final decision" within the meaning of 28 U.S.C. $\$ 1291$, which the government may appeal. ${ }^{119}$

\section{CONCLUSION}

Generally speaking, under the Bail Reform Act, which governs conditions of release for those accused of domestic crimes, a defendant will be released on bail unless the judge determines that he poses a risk of flight or danger to the community. If a defendant poses such a risk or danger, he will still be entitled to release, if there are conditions that can ameliorate those concerns. $^{120}$ An international extradition proceeding, however, is not considered a criminal prosecution. ${ }^{121}$ As the cases make clear, "[t]he rationale for not ordinarily granting bail in extradition cases is that extradition cases involve an overriding national interest in complying with treaty obligations."122 The developing case law reveals that although putative extraditees have been admitted to bail, ${ }^{123}$ the presumption against bail in international extradition

Magistrate's final decision. . . An appeal, if available, would be to the court of appeals.").

116. See Leitner, 627 F. Supp. at 740, aff'd, 784 F.2d 159 (2d Cir. 1986); United States v. Messina, 566 F. Supp. 740, 741 (E.D.N.Y. 1983).

117. See In re Extradition of Rouvier, 839 F. Supp. 537, 542-43 (N.D. Ill. 1993).

118. See United States v. Liu Kin-Hong, 83 F.3d 523, 523-24 (1st Cir. 1996); In re Extradition of Smyth, 976 F.2d 1535, 1535 (9th Cir. 1992); Hu Yau-Leung v. Soscia, 649 F.2d 914, 920 (2d Cir. 1981); United States v. Williams, 611 F.2d 914, 915 (1st Cir. 1979).

119. See In re Extradition of Kirby, 106 F.3d 855, 858-61 (9th Cir. 1996). See generally Gina Barry, Note, United States v. Kirby: The Case for Appellate Review of Grants of Bail by District Court Judges in International Extradition Cases, 21 W. NEW ENG. L. REV. 565 (1999) (criticizing rationale in Kirby and arguing that collateral order doctrine provides justification for review of district court decisions granting bail in international extradition cases absent Supreme Court rule defining what constitutes a final decision or delineating categories of decisions that are immediately appealable).

120. See 18 U.S.C. \$§ 3142(b)-(c) (2006).

121. See In re Extradition of Mainero, 950 F. Supp. 290, 295 (S.D. Cal. 1996).

122. Hababou v. Albright, 82 F. Supp. 2d 347, 352 (D.N.J. 2000); accord In re Extradition of Orozco, 268 F. Supp. 2d 1115, 1116-17 (D. Ariz. 2003); In re Extradition of Molnar, 182 F. Supp. 2d 684, 687 (N.D. Ill. 2002); United States v. Hills, 765 F. Supp. 381, 384-85 (E.D. Mich. 1991). As noted by the court in In re Extradition of Sacirbegovic, "if the accused were to be released on bond and thereafter absconded, the mere surrender of a quantity of cash or other property 'would hardly meet the international demand' and could cause the United States 'serious embarrassment."' 280 F. Supp. 2d 81, 83 (S.D.N.Y. 2003) (quoting Wright v. Henkel, 190 U.S. 40, 62 (1903)).

123. Putative extraditees have been able to demonstrate special circumstances warranting their admission to bail in a limited number of cases. See Kirby, 106 F.3d at 863-65 (delay prior to hearing and afterwards, cast cloud over proceedings by district court ruling section 3184 unconstitutional, uniqueness of case in that it concerned promoting harmony between supporters and detractors of cause of Catholics in Northern Ireland); Soscia, 649 F.2d at 920 (petitioner's age and background and lack of suitable detention facilities); In re Extradition of Valles, No. M- 
proceedings - either prior to or after the extradition hearing - usually carries the day. ${ }^{124}$

02-008, 2002 U.S. Dist. LEXIS 26711 (S.D. Tex. 2002) (alluding to factors identified in a decision by the Board of Immigration Appeals); In re Extradition of Bowey, 147 F. Supp. 2d 1365 (N.D. Ga. 2001) (no risk of flight or danger to community; need to participate in divorce proceeding directly related to extradition; likelihood of success in defending against criminal action in requesting country); In re Extradition of Gonzalez, 52 F. Supp. 725, 736 (W.D. La. 1999) (no risk of flight; substantial likelihood of success at extradition hearing because identification evidence lacked indicia of reliability); In re Extradition of Morales, 906 F. Supp. 1368, 1375-77 (S.D. Cal. 1995) (no risk of flight or danger to community; petitioner in custody for seven months and proceedings likely to be protracted; bail available for similarly situated putative extraditee in requesting country); In re Extradition of Nacif-Borge, 829 F. Supp. 1210, 1221-22 (D. Nev. 1993) (availability of bail for the underlying offense in requesting country; no risk of flight or danger to the community); United States v. Taitz, 130 F.R.D. 442 (S.D. Cal. 1990) (no risk of flight or danger to community; complex case involving 434 counts of fraud; health issues; impact on religious practices; requesting country's law allowed bail for one facing extradition); In re Mitchell, 171 F. 289, 290 (S.D.N.Y. 1909) (petitioner's need to consult with counsel in civil case involving his "whole fortune").

In cases involving provisional arrest warrants, some courts have applied a more liberal standard when ascertaining whether special circumstances are present. See Molnar, $182 \mathrm{~F}$. Supp. 2d at 689 (combination of factors: financial assistance petitioner provided to mother abroad, possible delay in the initiation of formal proceedings, fact that charges in requesting country initially dropped and then reinstated, petitioner had never been a fugitive, and willingness of friends to post home as security). In some cases, when a putative extraditee already has been admitted to bail in connection with a parallel deportation proceeding, bail has been granted in the extradition matter as well. See Shapiro v. Ferrandina, 355 F. Supp. 563, 566 (S.D.N.Y.), aff'd, 478 F.2d 894 (2d Cir. 1973); Artukovic v. Boyle, 107 F. Supp. 11, 14 (S.D. Cal. 1952), rev'd, 211 F.2d 565 (9th Cir. 1953).

124. See United States v. Liu Kin-Hong, 83 F.3d 523, 524-25 (1st Cir. 1996); Martin v. Warden, 993 F.2d 824, 827-28 (1 l th Cir. 1993); In re Extradition of Smyth, 976 F.2d 1535, 1536 (9th Cir. 1992); Salerno v. United States, 878 F.2d 317, 317-18 (9th Cir. 1989); In re Extradition of Russell, 805 F.2d 1215, 1216-17 (5th Cir. 1986); United States v. Leitner, 784 F.2d 159, 160-61 (2d Cir. 1986); United States v. Williams, 611 F.2d 914, 914-15 (1st Cir. 1979); In re Extradition of Mironescu, 296 F. Supp. 2d 632, 634 (M.D.N.C. 2003); Sacirbegovic, 280 F. Supp. 2d at 86-88; Orozco, 268 F. Supp. 2d at 1117; Borodin v. Ashcroft, 136 F. Supp. 2d 125, 132 (E.D.N.Y. 2001); Hababou, 82 F. Supp. 2d at 351-52; Duran v. United States, 36 F. Supp. 2d 622, 627-28 (S.D.N.Y. 1999); United States v. Bogue, No. 98 572-M, 1998 U.S. Dist. LEXIS 16784, at *11-12 (E.D. Pa. May 14, 1998); In re Extradition of Rovelli, 977 F. Supp. 566, 569 (D. Conn. 1997); Mainero, 950 F. Supp. at 293-96; Lo Duca v. United States, No. CV-95-713, 1995 WL 428636, at *15-16 (E.D.N.Y. July 7, 1995); In re Extradition of Sutton, 898 F. Supp. 691, 694-96 (E.D. Mo. 1995); In re Extradition of Siegmund, 887 F. Supp. 1383, 1385-87 (D. Nev. 1995); In re Extradition of Sidali, 868 F. Supp. 656, 657-59 (D.N.J. 1994); In re Extradition of Rouvier, 839 F. Supp. 537, $539-43$ (N.D. Ill. 1993); In re Extradition of Hamilton-Byrne, 831 F. Supp. 287, 290-91 (S.D.N.Y. 1993); In re Extradition of Heilbronn, 773 F. Supp. 1576, $1581-82$ (W.D. Mich. 1991); Hills, 765 F. Supp. at 386-89; United States v. Tang Yee-Chun, 657 F. Supp. 1270, 1272 (S.D.N.Y. 1987); United States v. Messina, 566 F. Supp. 740, 745 (E.D.N.Y. 1983); In re Klein, 46 F.2d 85 (S.D.N.Y. 1930). 
